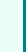

\title{
A Case of Neuroendocrine Cell Carcinoma with Sigmoidovesical Fistula
}

\author{
Tsutomu Kawaguchi $^{\mathrm{a}}$ Tsuyoshi $_{\text {Itoh }}{ }^{\mathrm{b}}$ Atsushi Toma ${ }^{\mathrm{b}}$ \\ Nobuaki Fuji $^{\text {b }}$ Takeshi Mazakic Kazuyo Naito $^{\text {b }}$ \\ Eigo Otsuji ${ }^{\mathrm{a}}$
}

${ }^{a}$ Division of Digestive Surgery, Department of Surgery, Kyoto Prefectural University of Medicine, and Departments of bSurgery and 'Pathology,

Kyoto Prefectural Yosanoumi Hospital, Kyoto, Japan

\section{Key Words}

Sigmoidovesical fistula · Neuroendocrine cell carcinoma · Chemotherapy · FOLFOX

\begin{abstract}
Colonic neuroendocrine cell carcinoma (NEC), which is a rare subtype of colon epithelial neoplasm, has been reported to show extremely aggressive characteristics with a 1-year survival rate of $20 \%$. We report herein a resected case of NEC that manifested bacterial sepsis due to sigmoidovesical fistula. Staged surgery consisted of resecting the sigmoid colon and part of the bladder four weeks after construction of an ileostomy to alleviate septic shock. The resected specimen was histologically diagnosed as NEC invading the wall of the urinary bladder with metastasis to the regional lymph nodes. The patient underwent four cycles of FOLFOX after surgery for additional treatment of residual metastatic lymph nodes around the abdominal aorta diagnosed preoperatively. Although the patient showed stable disease measured by computed tomography scan for the first three months after surgery, he rejected additional chemotherapy thereafter, and died ten months after the initial admission due to progression of residual tumor in the urinary bladder as well as the lymph nodes. This is the first case report describing colonic NEC manifesting perforation into the urinary bladder. Although the optimal chemotherapeutic regimen for colonic NEC has not yet been established, FOLFOX may be one of the choices.
\end{abstract}

\section{Introduction}

Neuroendocrine cell carcinoma (NEC) of the colon, sometimes described as small cell carcinoma of the alimentary tract, is an extremely rare tumor, representing less than $1 \%$ of colonic cancers $[1,2]$. Most patients are diagnosed at an advanced stage, presenting 
with clinical symptoms and macroscopic characteristics identical to colon adenocarcinoma. Because of its highly aggressive biological behavior, it progresses much faster than common adenocarcinoma of the colon, with early hemodynamic and lymphatic spread leading to a poor prognosis $[1,2]$. Although previous reports have suggested that tumor resection with subsequent chemo-radiotherapy could be one of the favorable treatments, the optimal therapeutic protocol including chemotherapeutic regimen has not yet been established [3]. We report a rare case of NEC of the colon with sigmoidovesical fistula (SVF). Palliative resection of the tumor followed by chemotherapy using the FOLFOX regimen is considered feasible.

\section{Case Report}

A 78-year-old man was transported by ambulance to our hospital with complaints of severe lower abdominal pain, fecaluria and high fever. On admission, his body temperature was $38^{\circ} \mathrm{C}$, heart rate was more than 100 beats $/ \mathrm{min}$, and blood pressure was $75 \mathrm{~mm} \mathrm{Hg}$, suggesting septic shock state. Laboratory data showed a white blood cell count of $15,100 / \mathrm{mm}^{3}$ and a C-reactive protein level of $9.5 \mathrm{mg} / \mathrm{dl}$. Urine sample contained significant amounts of white blood cells (100 counts/field), red blood cells (5099 counts/field) and bacteria (3+), compatible with urinary tract infection. Abdominal computed tomography (CT) scan demonstrated a mass lesion at the sigmoid colon with marked inflammatory change around the urinary bladder (fig. 1 ). Bacterial sepsis due to urinary tract infection caused by the sigmoid colon tumor penetrating the urinary bladder was highly suspected, although direct visualization of SVF was not detected. Emergency surgery including ileostomy for fecal diversion and urethral catheterization (triple lumen, 24 French) was performed immediately. The clinical course after emergency surgery was good, and staged operation was planned after additional preoperative examination. Hypotonic gastrografin enema showed sigmoid colon stenosis without apparent findings of SVF. CT scan also showed sigmoid stenosis due to tumor-like mass. Colonoscopy was not performed in order to avoid relapse of pyelonephritis by pressure-induced enlargement of the SVF. Serum tumor markers, such as carcinoembryonic antigen and carbohydrate antigen 19-9, were within normal limits. Based on the diagnosis of sigmoid colon cancer with SVF, the patient underwent the second surgery for tumor removal four weeks after the initial surgery. Surgical findings showed a large solid tumor invading the bladder wall. Enlarged lymph nodes were found along the inferior mesenteric artery as well as the abdominal aorta. Sigmoidectomy with partial resection of the bladder with D2 lymph node dissection was carried out. The tumor in the sigmoid colon was $82 \times 74 \mathrm{~mm}$ in size. Microscopic examination demonstrated that the tumor consisted of small round cells with nuclear atypia and had directly invaded and penetrated the bladder. Multiple lymph node metastases were also noted. Immunohistochemical examination demonstrated that more than $90 \%$ of the small cells were positive for CD56, which indicated a diagnosis of NEC of the sigmoid colon. The serum biomarker, neuronal-specific enolase specific for NEC, showed a high level of $31.9 \mathrm{ng} / \mathrm{ml}$ (cut-off level $12 \mathrm{ng} / \mathrm{ml}$ ) even after the second surgery.

The patient underwent four cycles of chemotherapy intravenously which consisted of 5-fluorouracil $\left(2,000 \mathrm{mg} / \mathrm{m}^{2}\right)$, levofolinate $\left(200 \mathrm{mg} / \mathrm{m}^{2}\right)$ and oxaliplatin $\left(85 \mathrm{mg} / \mathrm{m}^{2}\right)$ (FOLFOX regimen). Follow-up CT scan three months after the initiation of chemotherapy demonstrated that there was no change in the size of paraaortic lymph nodes (fig. 2). However, the patient refused to continue any additional treatment. Thereafter, the metastatic lymph nodes and local recurrent tumor grew rapidly and he died ten months after the second surgery.

\section{Discussion}

Colorectal NEC, which has been described as small cell carcinoma in the past, is an extremely rare histological type, representing $0.03-0.2 \%$ of all colorectal cancers $[4,5]$. Morphological and biological aggressiveness similar to that of small cell carcinoma of the lung is its notable feature. Hung [1] reviewed 39 cases of small cell carcinoma of the colon and found that the 1-year survival rate was only $10 \%$ with a mean survival time of approximately 6 months. Most of the patients were diagnosed at an advanced stage. Radical resection at an early stage has been considered the only cure. However, the 
prognosis of these patients is sometimes dismal even when diagnosed at an early stage. Thus, further investigation with regard to its biology as well as therapeutic modality is warranted.

Systemic chemotherapy and/or radiation therapy have been therapeutic alternatives especially for advanced NEC, although there are no established standard regimens. Thirty-eight cases of advanced colorectal NEC treated with chemotherapy were reviewed in our literature survey using the key words 'neuroendocrine cell carcinoma', 'colon' and 'chemotherapy', to search the MEDLINE database between 1983 and 2008 (table 1) [3, 614]. We analyzed these 38 cases in addition to our case, and 24 and 15 cases showed liver and lymph node metastases. Regarding outcomes, 3 cases achieved complete response and 10 cases partial response, and the response rate including complete response, partial response and no change was $38 \%$. Concerning the chemotherapeutic regimens, cisplatin (CDDP) was administered to 21 cases, and CPT-11 and etoposide were combined in 5 and 10 cases, respectively. These regimens were considered based on the current regimen of small cell carcinoma of the lung.

Recently several new regimens, such as FOLFOX and/or FOLFIRI, have been reported to show more favorable prognoses than conventional regimens for patients with common advanced or recurrent colorectal cancers, and the side effects were tolerable. Moreover, as the patient's renal function and digestive function were impaired, CDDP or CPT-11 was not indicated for systemic chemotherapy. Therefore, we treated our case using FOLFOX and obtained no change for three months without progression of either metastasized lymph nodes or local residual tumor. Sunose [15] also reported that liver metastasis showed a clinical response to the FOLFOX regimen. Although the results are still preliminary, sunitinib has been reported to be clinically effective for neuroendocrine cancer of the lung and pancreas $[16,17]$. Combination treatment using chemotherapeutic and molecular targeting drugs may achieve a more favorable response. Multicenter clinical trials may be an efficient way of elucidating useful regimens especially for this rare type of cancer. 
Table 1. Reported cases of advanced colorectal NEC with metastases and the regimen used for chemotherapy and the response to treatment

\begin{tabular}{|c|c|c|c|c|c|}
\hline $\begin{array}{l}\text { Refer- } \\
\text { ence }\end{array}$ & Year & $\begin{array}{l}\text { Lo- } \\
\text { ca- } \\
\text { tion }\end{array}$ & $\begin{array}{l}\text { Site of } \\
\text { metastasis }\end{array}$ & Regimen & $\begin{array}{l}\text { Re- } \\
\text { sponse }\end{array}$ \\
\hline 6 & 2008 & $\mathrm{C}$ & liver & CDDP+etoposide, 5-FU+CDDP+etoposide (HAI) & $\mathrm{PD}$ \\
\hline 7 & 2008 & $\mathrm{R}$ & LN & CDDP+etoposide, CPT-11+CDDP & $\mathrm{PR}$ \\
\hline 8 & 2008 & $\mathrm{R}$ & local invasion & IFL+radiation (preoperative therapy) & $\mathrm{PR}$ \\
\hline 18 & 2008 & A & liver & 5-FU+l-LV (HAI), CPT-11, FOLFOX6 & PR \\
\hline 19 & 2007 & $\mathrm{R}$ & local & $\mathrm{CDDP}+\mathrm{UFT}$ & PD \\
\hline 20 & 2007 & $\mathrm{~T}$ & $\mathrm{LN}, \mathrm{P}$ & $\mathrm{CPT}-11$ & $\mathrm{PD}$ \\
\hline \multirow[t]{2}{*}{21} & 2007 & $\mathrm{C}$ & liver & $\mathrm{CDDP}+\mathrm{CPT}-11$ & $\mathrm{CR}$ \\
\hline & & & LN, adrenal & $\begin{array}{l}\text { CDDP+etoposide, cyclophosphamide+ } \\
\text { doxorubicin+vincristine }\end{array}$ & PR \\
\hline 22 & 2007 & $\mathrm{R}$ & LN, P & IFL & PD \\
\hline 9 & 2007 & $\mathrm{~T}$ & liver, $\mathrm{LN}$ & hepatectomy+chemotherapy (unknown) & CR \\
\hline \multirow[t]{6}{*}{10} & 2006 & $\mathrm{R}$ & liver & CDDP+etoposide & $\mathrm{PD}$ \\
\hline & & $\mathrm{S}$ & liver & FOLFIRI, TACE & PD \\
\hline & & $\mathrm{R}$ & liver, bone & 5-FU+dacarbazine+epirubicin & $\mathrm{PD}$ \\
\hline & & $\mathrm{R}$ & liver, lung, LN & CDDP+etoposide & $\mathrm{PR}$ \\
\hline & & $\mathrm{C}$ & $\mathrm{P}$ & oral chemotherapy & $\mathrm{PR}$ \\
\hline & & $\mathrm{R}$ & liver & xeloda & $\mathrm{PR}$ \\
\hline 15 & 2006 & $\mathrm{R}$ & local, liver & CDDP+CPT-11, IFL, FOLFOX4 & $\mathrm{PR}, \mathrm{NC}$ \\
\hline 23 & 2006 & $\mathrm{~T}$ & liver, $\mathrm{P}$ & $\mathrm{CDDP}+\mathrm{CPT}-11$ & $\mathrm{PD}$ \\
\hline \multirow[t]{2}{*}{24} & 2006 & $\mathrm{~A}$ & liver, $\mathrm{LN}$ & CDDP+5-FU (HAI) & $\mathrm{PD}$ \\
\hline & & $\mathrm{D}$ & liver, $\mathrm{P}$ & 5-FU (HAI), 5-FU+1-LV & $\mathrm{PD}$ \\
\hline \multirow[t]{2}{*}{25} & 2005 & $\mathrm{R}$ & liver & 5-FU, TS-1 & PD \\
\hline & & $\mathrm{R}$ & liver & $\mathrm{CDDP}+5 \mathrm{FU}(\mathrm{HAI}), \mathrm{FAM}+\mathrm{CDDP}$ & $\mathrm{PD}$ \\
\hline 26 & 2004 & $\mathrm{R}$ & LN & CDDP+etoposide+paclitaxel & $\mathrm{PR}$ \\
\hline 27 & 2004 & $\mathrm{R}$ & liver & CDDP+5-FU (HAI)+l-LV & PD \\
\hline 28 & 2004 & $\mathrm{~T}$ & local invasion & $\mathrm{CDDP}+\mathrm{CPT}-11$ & $\mathrm{CR}$ \\
\hline 29 & 2003 & $\mathrm{R}$ & liver, LN, local & $\mathrm{CDDP}+5-\mathrm{FU}(\mathrm{HAI})$ & $\mathrm{PD}$ \\
\hline 11 & 2002 & $\mathrm{R}$ & liver, bone, skin & unknown & $\mathrm{PD}$ \\
\hline 12 & 2002 & A & liver & $\begin{array}{l}\text { vincristin, etoposide, adriamycin, carboplatin, } \\
\text { taxotere }\end{array}$ & $\mathrm{PD}$ \\
\hline 30 & 2002 & $\mathrm{R}$ & $\begin{array}{l}\text { liver, LN, local, } \\
\text { bone, skin }\end{array}$ & CDDP+etoposide & $\mathrm{PD}$ \\
\hline 31 & 2002 & $\mathrm{R}$ & LN & CDDP+etoposide & $\mathrm{CR}$ \\
\hline \multirow[t]{3}{*}{13} & 2002 & $\mathrm{C}$ & $\mathrm{LN}$ & unknown & lost to \\
\hline & & & & & $\begin{array}{l}\text { follow- } \\
\text { up }\end{array}$ \\
\hline & & $\mathrm{D}$ & liver, $\mathrm{LN}, \mathrm{P}$ & unknown & $\mathrm{PD}$ \\
\hline 2 & 1999 & $\mathrm{R}$ & liver, LN, bone & $\mathrm{CDDP}+5-\mathrm{FU}$ & $\mathrm{PR}$ \\
\hline 14 & 1999 & $\mathrm{~S}$ & liver, $\mathrm{LN}$ & $5-F U+1-L V$ & PD \\
\hline 32 & 1998 & $\mathrm{R}$ & liver, local & CDDP+etoposide & $\mathrm{PD}$ \\
\hline 33 & 1996 & A & $\mathrm{P}$ & CDDP+etoposide+adriamycin & $\mathrm{PD}$ \\
\hline 34 & 1996 & $\mathrm{~T}$ & $\mathrm{P}$ & $\mathrm{CDDP}+5-\mathrm{FU}$ & $\mathrm{PD}$ \\
\hline
\end{tabular}

$\mathrm{A}=$ Ascending colon; $\mathrm{C}=$ cecum $; \mathrm{CDDP}=$ cisplatin; $\mathrm{CR}=$ complete response $\mathrm{D}=$ descending colon; $\mathrm{FAM}=5$-fluorouracil+adriamycin +mitomycin; $\mathrm{HAI}=$ hepatic arterial infusion; $\mathrm{IFL}=\mathrm{CPT}-11+5-\mathrm{FU}+\mathrm{LV}$; $\mathrm{LN}=$ lymph node; $\mathrm{LV}=$ leucovorin; $\mathrm{NC}=$ no change; $\mathrm{P}=$ peritoneum; $\mathrm{PD}=$ progressive disease; $\mathrm{PR}=$ partial response; $\mathrm{R}=$ rectum; $\mathrm{S}=$ sigmoid colon; $\mathrm{T}=$ transverse colon; $\mathrm{TACE}=$ transcatheter arterial chemoembolization. 


\begin{tabular}{r|l|l|l} 
Case Reports in & $\begin{array}{l}\text { Case Rep Gastroenterol 2010;4:178-184 } \\
\text { D0I: 10.1159/000314197 }\end{array}$ & Published online: May 19, 2010 & $\begin{array}{l}\text { O 2010 S. Karger AG, Basel } \\
\text { ISSN 1662-0631 } \\
\text { www.karger.com/crg }\end{array}$ \\
\hline
\end{tabular}

Fig. 1. CT scan demonstrated a mass lesion at the sigmoid colon with marked inflammatory change around the urinary bladder. There was an air density lesion in the wall of the bladder (arrow).

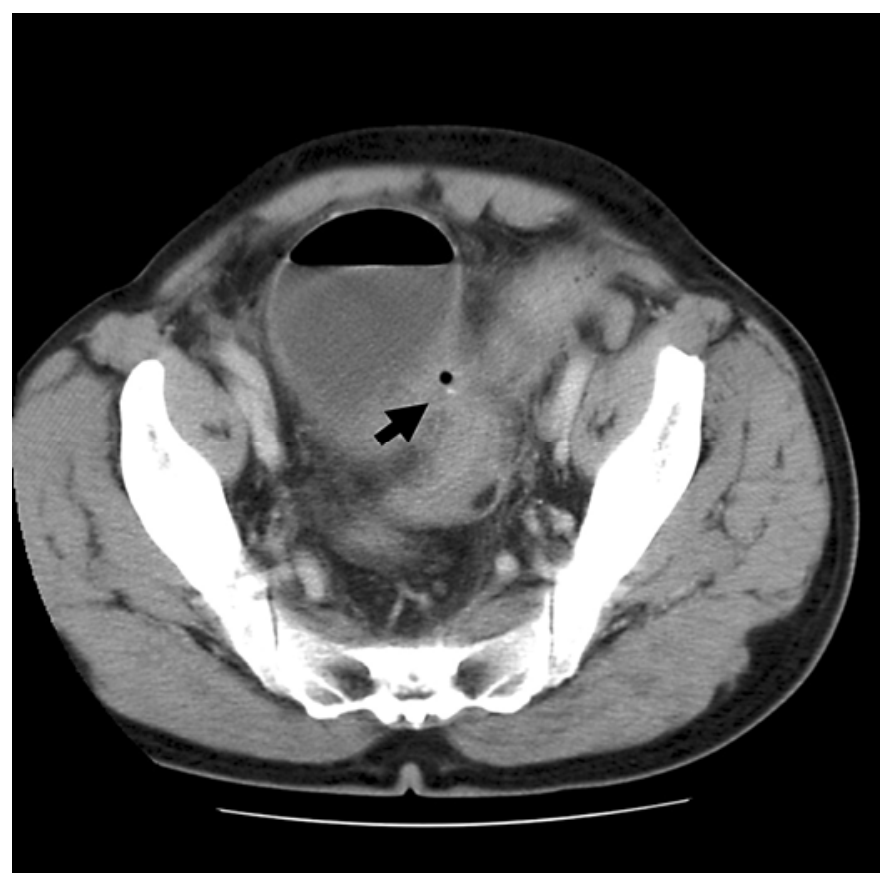

Fig. 2. Follow-up CT scan three months after the initiation of chemotherapy demonstrated no change in the size of the paraaortic lymph nodes. a Seven weeks after the first surgery, some paraaortic lymph nodes (arrow) demonstrated findings compatible with metastasis. b Three months after the initiation of chemotherapy, the size of these lymph nodes had not changed (arrow).
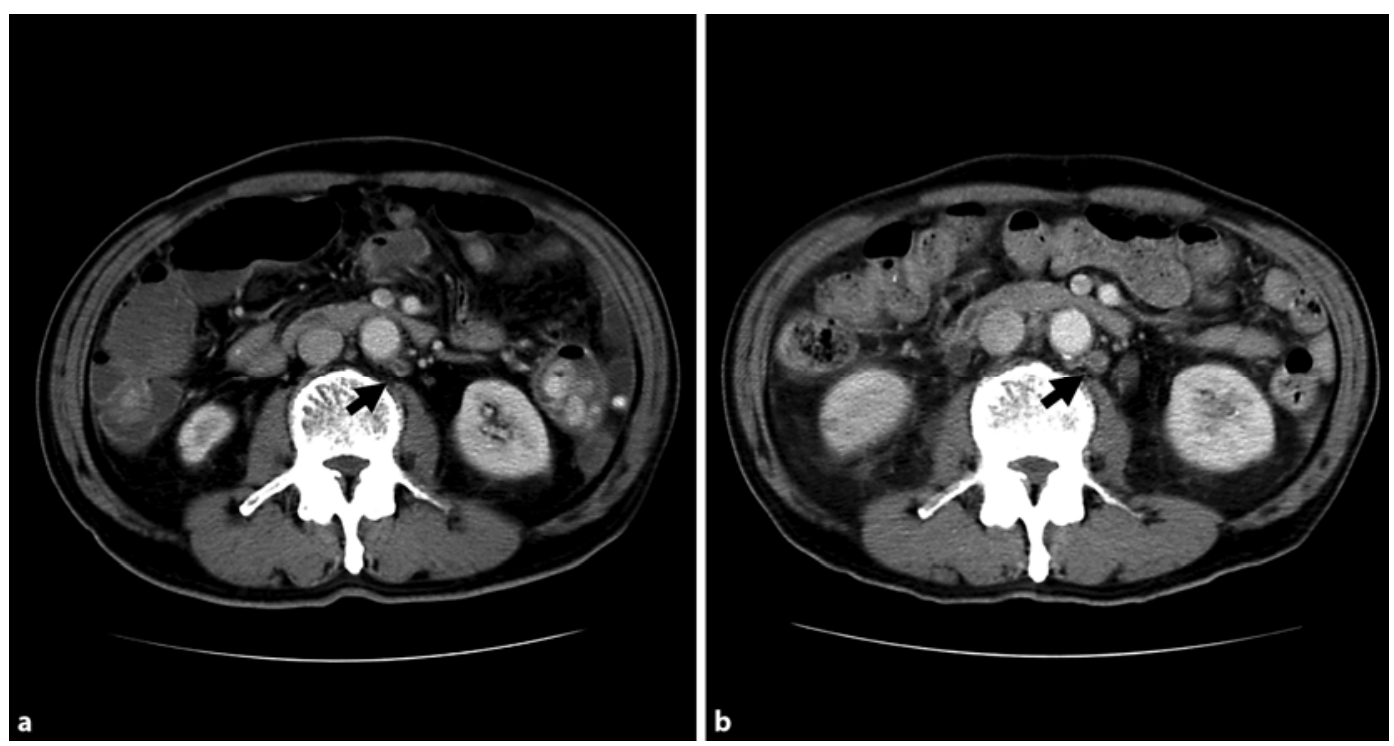


\section{References}

1 Hung SSJ: Small cell carcinoma of the colon - a case report and literature review. J Clin Gastroenterol 1989;11:335-339.

2 Okuyama T, Korenaga D, Tamura S, et al: The effectiveness of chemotherapy with cisplatin and 5-fluorouracil for recurrent small cell neuroendocrine carcinoma of the rectum: report of a case. Jpn J Surg 1999;29:165-169.

-3 Oshima $\mathrm{Y}$, Isaka N, Takeuchi T, et al: A case of long-term survival after chemotherapy for liver metastases from endocrine cell carcinoma of the colon (in Japanese with English abstract). J Jpn Surg Assoc 2008;69:2331-2336.

4 Nishimura Y, Sekine T, Kobayashi T, et al: Clinicopathological study of rare histological types of colorectal cancer: multi-institutional questionnaire study (in Japanese with English abstract). Nippon Daicho Komonbyo Gakkai Zasshi 2004;57:132-140.

5 Otsuka M, Kato Y: Clinicopathological study of poorly differentiated and undifferentiated carcinoma of the large intestine: classification and special reference to the endocrine cell carcinoma (in Japanese with English abstract). Jpn J Gastroenterol Surg 1992;40:757-763.

6 Shimakage N: A case of primary endocrine cell carcinoma (small cell carcinoma) of the cecum with the onset of ileocecal intussusceptions (in Japanese with English abstract). Niigata Med J 2008;122:49-55.

7 Takayama M, Mochiduki T, Tateishi K, et al: A case of rectal endocrine cell carcinoma significantly reduced by chemotherapy using the regimens against small cell carcinoma of the lung (in Japanese with English abstract). Endosc Forum Dig Dis 2008;24:18-24.

8 Sendo H, Idei H, Shirakawa S, et al: Effectiveness of chemoradiation therapy against endocrine cell carcinoma of the rectum: report of a case (in Japanese with English abstract). Jpn J Gastroenterol Surg 2008;41:1643-1648.

-9 Butte JM, Torres J, Duarte I, et al: Composite tumor of the colon with liver metastases (in Spanish with English abstract). Cir Esp 2007;82:128-130.

10 Jung SH, Kim HC, Yu CS, et al: Clinicopathologic characteristics of colorectal neuroendocrine tumor (in Korean with English abstract). Korean J Gastroenterol 2006;48:97-103.

11 Luh JY, Han ES, Simmons JR, et al: Poorly differentiated colon carcinoma with neuroendocrine features presenting with hypercalcemia and cutaneous metastases. Am J Clin Oncol 2002;25:160-163.

12 Scherwitz P, Lindenfelser R, Krüger I: Localization of primary small cell carcinoma with liver metastasis: a rare combination of colonic adenocarcinoma and undifferentiated small cell carcinoma (in German with English abstract). Chirurg 2002;73:859-861.

13 Ouban A, Nawab RA, Coppola D: Diagnostic and pathogenetic implications of colorectal carcinomas with multidirectional differentiation: a report of 4 cases. Clin Colorectal Cancer 2002;1:243-248.

14 Lortholary AH, Cadeau SD, Bertrand GM, et al: Humoral hypercalcemia in patients with colorectal carcinoma. Cancer 1999;86:2217-2221.

15 Sunose Y, Takeyoshi I, Ogawa T, et al: A giant endocrine cell cancer of the rectum that remained progression free for 20 months with multidisciplinary treatment (in Japanese with English abstract). Nippon Rinshogeka Gakkai Zasshi 2006;67:1848-1852.

16 Dham A, Truskinovsky AM, Dudek AZ, et al: Thymic carcinoid responds to neoadjuvant therapy with sunitinib and octreotide: a case report. J Thorac Oncol 2008;3:94-97.

17 Kulke MH, Lenz HJ, Meropol NJ, et al: Activity of sunitinib in patients with advanced neuroendocrine tumors. J Clin Oncol 2009;26:3403-3410.

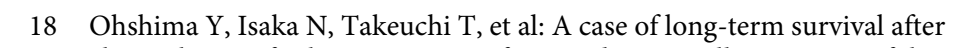
chemotherapy for liver metastases from endocrine cell carcinoma of the colon (in Japanese with English abstract). Jpn J Gastroenterol Surg 2008;69:2331-2336.

$\checkmark 19$ Morimoto Y, Ookura M, Iwagaki H, et al: A case of rectal neuroendocrine carcinoma metastatic to the brain (in Japanese with English abstract). Nippon Daicho Komonbyo Gakkai Zasshi 2007;60:167-172.

20 Ishizuka N, Ishibashi K, Ohsawa T, et al: Rapidly growing endocrine cell carcinoma of the colon with elevated expression of vascular endothelial growth 
factor (VEGF) and VEGF-C: a case report (in Japanese with English abstract). Nippon Daicho Komonbyo Gakkai Zasshi 2007;60:269-275.

21 Takeshima K, Yamafuji K, Asami A, et al: A long survival case of endocrine cell carcinoma of the cecum (in Japanese with English abstract). Jpn J Gastroenterol Surg 2007;40:757-763.

22 Kohno F, Matsuda S, Shushida Y, et al: A case of endocrine cell carcinoma of the colon (in Japanese). Rinshogeka 2007;62:139-143.

23 Yodonawa S, Ogawa I, Goto Y, et al: A case of juvenile endocrine cell carcinoma of the transverse colon (in Japanese with English abstract). Jpn J Gastroenterol Surg 2006;39:406-411.

24 Ohnishi T, Kanoh T, Murakami M, et al: Neuroendocrine carcinoma of colon report of two cases (in Japanese with English abstract). Jpn J Gastroenterol Surg 2006;39:509-515.

25 Morioka N, Miyashita K, Aizawa K, et al: Two cases of endocrine cell carcinoma of the rectum (in Japanese with English abstract). Endosc Forum Dig Dis 2005;21:163-167, 187.

26 Kabeshima Y, Takahashi M, Kameyama N, et al: Solitary cervical metastasis of poorly differentiated adenocarcinoma with neuroendocrine differentiation of the rectum: report of a case (in Japanese with English abstract). Jpn J Gastroenterol Surg 2004;37:241-246.

27 Yamauchi K, Miyata T, Okada N, et al: A case of endocrine cell carcinoma of the rectum (in Japanese with English abstract). Nippon Rinshogeka Gakkai Zasshi 2004;65:751-755.

28 Tsutani Y, Aoki H, Harano M, et al: Effectiveness of neoadjuvant chemotharapy against neuroendocrine carcinoma of the colon with duodenal invasion; report of a case (in Japanese with English abstract). Jpn J Gastroenterol Surg 2004;37:14851490.

29 Tsujie M, Shibata N, Nomura T, et al: A case of endocrine cell carcinoma of the rectum (in Japanese with English abstract). Jpn J Gastroenterol Surg 2003;36:240 244.

30 Okada S, Fujioka M, Taguchi S, et al: A case of neuroendocrine carcinoma of the rectum (in Japanese). Nippon Shokakibyo Gakkai Zasshi 2002;99:282-288.

31 Yukawa N, Akaike M, Sugimasa Y, et al: 42-Months survival following chemotherapy for small cell rectal carcinoma (in Japanese with English abstract). Jpn J Gastroenterol Surg 2002;35:1443-1447.

32 Shimada K, Ueno S, Oshima Y, et al: A case of endocrine cell carcinoma of the rectum (in Japanese with English abstract). Jpn J Gastroenterol Surg 1998;59: 1346-1349.

33 Nasu J, Kotake K, Koyama Y, et al: Endocrine cell carcinoma of the colon: report of a case (in Japanese with English abstract). Nippon Daicho Komonbyo Gakkai Zasshi 1996;49:161-166.

34 Kobayashi M, Yasuda A, Furukawa M, et al: A case of endocrine cell carcinoma of the transverse colon (in Japanese with English abstract). Endosc Forum Dig Dis 1996;12:116-120. 